IJOLTL, Vol. 2, No. 3, September 2017

p ISSN: 2502 2326; e-ISSN: 2502 8278

Http://ijolt1.pusatbahasa.or.id; Email: ijolt1@gmail.com

Center of Language and Culture Studies, Surakarta, Indonesia

Budiasih, Tri Latifah; Andayani; Rohmadi, Muhammad. 2017. Illocution in Speech Acts

By Foreign Students in Indonesian as a Foreign Language Classes. IJOLTL (2017), 2(3): 213 226.

\title{
ILLOCUTION IN SPEECH ACTS BY FOREIGN STUDENTS IN INDONESIAN AS A FOREIGN LANGUAGE CLASSES
}

\author{
Latifah Tri Budiasih ${ }^{1}$ \\ Andayani $^{2}$ \& Muhammad Rohmadi ${ }^{3}$ \\ ${ }^{1}$ Thesis Supervisee \\ ${ }^{2 \& 3}$ Thesis Supervisors \\ Graduate Program of Indonesian Language Education \\ Faculty of Teacher Training and Educational Sciences, \\ Sebelas Maret University \\ JL.IR.Sutami No. 36A, Kentingan, Surakarta, Central Java, Indonesia \\ Email: latifah.tribudiasih@ gmail.com; \\ andayani@staff.uns.ac.id\&mamad_r76@staff.uns.ac.id
}

\begin{abstract}
This research explores illocution in speech acts by foreign students in Indonesian as a Foreign Language classes at Sebelas Maret University. Illocution is a speech that shows the state of language relating to the situation in general and more free and aims to express something from the speaker to the partner. This research aims to describe the forms of student illocution in Indonesian Language classes. This study used qualitative approach with naturalistic design. Data were collected using observation, interviews, and document analysis. The data of illocution acts included assertive, declaration, directives, commissive, and expressive in learning activities. The study revealed that students applied assertive, directives, commissive and expressive as their main speech acts during learning Indonesian language in the classroom especially in the oral uses for communications.
\end{abstract}

Key words: illocution, student, Indonesian Language.

\section{INTRODUCTION}

Humans are social beings who at all times and every time always need others. Given these traits, language can bridge humans to interact with each other. In interacting, people use various media and one of them is language. Through language, people can exchange ideas, exchange stories and even exchange information that may be needed. In other words, language is a major component of interaction. In addition to understanding how the context of speech is used, people in the language must also understand whether a proper utterance used to convey something to be conveyed without any misunderstandings between speakers with partners said.

The importance of understanding the various aspects of speech acts is a must, so that communication can be well established. The existence of understanding between the speaker and the spoken partner is a very important thing that will indicate that the communication is running smoothly. Handayani, Megawati, and Malia (2016:306), in 
IJOLTL, Vol. 2, No. 3, September 2017

p ISSN: 2502 2326; e -ISSN: 2502 8278

Http://ijolt1.pusatbahasa.or.id; Email: ijolt1@gmail.com

Center of Language and Culture Studies, Surakarta, Indonesia

Budiasih, Tri Latifah; Andayani; Rohmadi, Muhammad. 2017. Illocution in Speech Acts

By Foreign Students in Indonesian as a Foreign Language Classes. IJOLTL (2017), 2(3): 213 226.

his study contains Searle statement that speech acts are divided into three kinds. Three kinds of speech acts in the actual use of language in the community are locutionary acts, illocutionary acts, and perlocutionary acts.

The development of Indonesian Language learners in the world is improving. This improvement of the foreign speakers who learn Indonesian Language is also proved by the increasing number of students of Indonesian Language that come and study in Indonesia. This can be seen from the improvement of Indonesian Language learners numbers that stated in some of language centre and language offices at Indonesian. Grade levels in the Indonesian Language learning, especially in Implementing Technical Unit Languages in the Sebelas Maret University, there are three levels. Basic level or a beginner, intermediate or moderate levels, and advanced. In each of these grade levels there are a wide variety of language mastery by students.

Ability and mastery of the student is always increasing. On a basic level, students are still experiencing difficulty in speaking Indonesia either by oral or writing, especially students at all has never heard of or knowing the language of Indonesia in his country. But at the next level-grade levels, students have become accustomed to using the language of Indonesia. Even in everyday life outside the classroom, the students often use Indonesia language to communicate, especially with the people of Indonesia. It signifies that the student has a very positive attitude towards learning Indonesian Language.

Indirectly, the foreign student is the second language learner. Learning a second language is the mother tongue acquisition implications (Brown, 1994:49). Further, Brown gave the seven principles of learning B2 namely as follows: (1) should always be practiced in learning second language; (2) impersonate basically is language learning activities; (3) impersonate in learning the first language that is mimicked the sounds separately, then mimicked the words and then sentences; (4) language learning starting from the activities of listening, speaking, reading, and writing; (5) the listening, speaking, reading and writing is the natural order in language learning; (6) language learning means learning without translating, and (7) of learning a second language can be started by using the language in a simple to the more complex. In this case, if you want to master a second language, then the simplest thing is to use it in everyday life from words, sentences are simple, to the words and sentences are more complex.

In connection with this, it aims to describe the illocution on the speech acts of students foreigners in Learning Indonesian Language in the form of acts of said assertive/representative, directive, declaration, commissive, and expressive in the Indonesian Language Learning at Implementing Technical Unit Language Sebelas Maret University.

\section{REVIEW OF LITERATURE}

\subsection{Illocution as one of the areas in the study of pragmatics}

Pragmatics is a branch of linguistics that studies on the use of languages that integrate with grammar which consists of phonology, morphology, syntax, and semantics (Leech, 2011:18). In contrast to Leech, Yule (2006:3-4) define Pragmatics on 
IJOLTL, Vol. 2, No. 3, September 2017

p ISSN: 2502 2326; e -ISSN: 2502 8278

Http://ijolt1.pusatbahasa.or.id; Email: ijolt1@gmail.com

Center of Language and Culture Studies, Surakarta, Indonesia

Budiasih, Tri Latifah; Andayani; Rohmadi, Muhammad. 2017. Illocution in Speech Acts

By Foreign Students in Indonesian as a Foreign Language Classes. IJOLTL (2017), 2(3): 213 226.

the four scope, the first pragmatic is the study of speaker meaning is, the second pragmatic is the study of contextual meaning, third pragmatic is the study of how communitcated gets more than is said, and the last is the pragmatic study of expression of relative distance .

The first speech was conveyed by United Kingdom nationals, philosopher John L. Austin, who was then speaking in 1955 at Harvard University and published in 1962 under the title How To Do Things With Words. However, the theory of speech act itself is more introduced by Searle said that in daily life, there are at least three types of speech acts. He further said that speech acts divided into three types, namely locution (locutionary act), ilocution (illocutionary act), and perlocution (perlocutionary act) (Searle, 1969:23-24).

The orientation on the experts, Isnawati, Dwi, Anam, and Diana in her research contained a statement that "suggests that in uttering a sentence, a speaker is generally involved in three different acts: "locutionary act, illocutionary act, and perlocutionary $a c t$ ". The three kinds of speech acts in the actual language usage in the community are locutionary acts, illocutionary acts, and perlocutionary acts (2012:501). This means that when people talk, they use the language to accomplish a variety of functions such as expressing different emotions, starting from opinion or even insulting someone. All of the things described earlier can be said to act speech in the process of speaking. Furthermore, he stated that in the speech acts study, three things to consider, namely the language used, the intention of the conversation, and the interaction in the social context

The act of locution or can be called with The Act of Saying Something, is a speech actsthat aims to declare something (Wijana, 1996:17). The act of illocution or commonly referred to as The Act of Doing Something, is a speech act aimed at doing something (Parera, 1991:151). While perlocution acts is a speech act that aims to declare something with the intention to influence the opponent said certain effects or to give a certain effect to partners said (Leech, 1983:199). Sulistyo (2013:6) states that the speech acts is said person's ability in using language to convey messages or for purposes of speakers to partner said. From the description of the speech actsof some experts, it can be inferred that the speech acts is a person's skills in spoken language with the aim to convey messages to the partner said by paying attention to the context of the speech. Speech acts are divided into three, namely locution, illocution, and perlocution.

\section{a. Assertive}

Assertive or representative is a speech act of stating, proposing, bragging, complaining, expressing opinions, and reporting. Similar in the sense that, Ilyas and Khushi (2012:501), gives a sense of assertive illocution, "an assertive act counts as an attempt to explain the actual state of affairs comprising phrases used to address a specific idea, proposition or belief. These acts include asserting that, concluding, informing, predicting and reporting". Follow illocution assertive is a speech is used to convey a particular idea, where the speakers attached to the truth of the proposition expressed or confidence expressed to speakers partners said such as affirm something, inform things, concluded, and reported something. 
IJOLTL, Vol. 2, No. 3, September 2017

p ISSN: 2502 2326; e -ISSN: 2502 8278

Http://ijolt1.pusatbahasa.or.id; Email: ijolt1@gmail.com

Center of Language and Culture Studies, Surakarta, Indonesia

Budiasih, Tri Latifah; Andayani; Rohmadi, Muhammad. 2017. Illocution in Speech Acts

By Foreign Students in Indonesian as a Foreign Language Classes. IJOLTL (2017), 2(3): 213 226.

\section{b. Directives}

Directives isa speech that aims to produce an effect to a speech partner in the form of an action or has the intention to make a speech partner doing something. The function of speech acts directive according to Rahardi (2009:17), such as ordering, commanding, begging, demanding, and advising.

\section{c. Declarative (Declarations)}

Declarative (declarations) is a speech that falls into the category of a very specific act of saying such as firing, punishing, and hiring. This speech act is intended to create things such as status, circumstances and so forth from the speakers to the said partner (Yule, 1996:94).

\section{d. Commissives}

Comissive is a speech act where the speakers attached to an action in the future. These commissive include promising, offering, and swearing (Rahardi, 2009:18).

\section{e. Expressives}

Expressives is a speech act which has the function as a disclosure of psychological attitude of the speaker toward the state implied in the illocution. The action to express this expressive attitude according to Rahardi (2009:18), like to say thank you, congratulate, apologize, blame, praise, and say condolences.

\subsection{Illocution on Foreign Student Speech in Indonesian Language Learning}

Follow up said illocution called the act of doing something .Altikriti (2011: 1376), said that:

"once the illocutionary act is satisfied, its propositional content fits the existing state of affairs in general Independently in the world. This expresses a belief, making the words fit the words and commit the speaker to the truth of what is asserted, for example: asserting that, reporting, instructing, concluding, responding, wishing, etc.".

One of the follow illocution indicates the State of the language relating to the circumstances in General and more free. Further he said that acts of illocution have the goals presented speakers to partner said that words spoken were words indeed would like delivered. With the illocution, speakers can convey what it wants against the partner said, such as affirming something, report something, instructs something, responding to a speech, expect partners to understand the purpose of said speakers, and so on.

It can be said that the acts of said illocution is the most important speech acts in the study and understanding of the acts of said (Nadar, 2013:14). Further, Nadar said that speech acts is a criminal illocution said said the articulated by the speakers with the purpose to achieve something desirable at the time said something, like the action of States, promises, apologies, threatens, foretells, commanding, ask, etc. 
IJOLTL, Vol. 2, No. 3, September 2017

p ISSN: 2502 2326; e -ISSN: 2502 8278

Http://ijolt1.pusatbahasa.or.id; Email: ijolt1@gmail.com

Center of Language and Culture Studies, Surakarta, Indonesia

Budiasih, Tri Latifah; Andayani; Rohmadi, Muhammad. 2017. Illocution in Speech Acts

By Foreign Students in Indonesian as a Foreign Language Classes. IJOLTL (2017), 2(3): 213 226.

Searle (1968:10), said that the shareholder said this illocution can be classified according to the activity in five kinds of forms of speech that each has it is communicative function. The five kinds of forms of speech are assertive or representative, directive, Declaration, commissives, and expressive.

Learning Indonesian Language in Technical Implementing Language Sebelas Maret University followed by six foreign students, namely Abdul (A), Berth (B), Jung $(\mathrm{J}), \mathrm{Nedu}(\mathrm{Nd})$, and $\mathrm{Num}(\mathrm{Nm})$, as for the $(\mathrm{Pg})$ is the abbreviation for Indonesian Language teacher.

\section{METHODS}

The methods in this research is a qualitative approach. The qualitative approach is an approach that aims to build knowledge statement based on constructive or perspective - a perspective partisipatori (Creswell, 2003:18). This research included in this type of case study research, where research case studies delve phenomena of a certain time and activities, as well as collecting detailed information using a variety of data collection procedures for cases of that happening (Afifuddin Ahmad Saebani, 2009:87). The object of the research obtained from research data in the form of a follow up said illocution, namely assertive, directives, declarations, commissives, and expressives Indonesian Language students.

Research data consists of primary data and secondary data. Primary data is the first data obtained, recorded and collected by researchers (Anwar, 2014:104). Primary Data in this study are obtained directly by researchers through observation and interview against the Indonesian Language teachers, foreign students or Indonesian Language learners, and the manager or coordinator of the Indonesian Language in Technical Implementing (UPT) Language Sebelas Maret University. Secondary data is data that is not observed by researchers directly, for instance through other people or documents (Sugiyono, 2015:193). In this research, secondary data obtained from researchers documents, photos, and videos in the Indonesian Language learning activities in the form of acts of said locution, illocution, and perlocution by students in Implementing Technical Unit Language Sebelas Maret University. The data source in this research there are three, i.e. informant, documents and library studies.

The technique of data collection in this research is with techniques observation, interviews, and document studies. The validity of the data (content analysis) is a guarantee of stability summary and interpretation of meanings as a result of research (Sutopo, 2002:79). The validity of the data used in this study i.e. the technique of triangulation, through a triangulation source, triangulation theory and triangulation methods.

\section{RESULT AND DISCUSSION}

\subsubsection{Assertive}

Illocution assertive is a speech is used to convey a particular idea, where the speakers attached to the truth of the proposition expressed or confidence expressed to speakers partners said such as affirm something, inform things, concluded, and reported 
IJOLTL, Vol. 2, No. 3, September 2017

p ISSN: 2502 2326; e -ISSN: 2502 8278

Http://ijolt1.pusatbahasa.or.id; Email: ijolt1@gmail.com

Center of Language and Culture Studies, Surakarta, Indonesia

Budiasih, Tri Latifah; Andayani; Rohmadi, Muhammad. 2017. Illocution in Speech Acts

By Foreign Students in Indonesian as a Foreign Language Classes. IJOLTL (2017), 2(3): 213 226.

something. Illocution assertive/Representative found in Indonesian Language learning in Implementing Technical Unit language of the Sebelas Maret University as follows.

(1) Pg : :Mungkin kamu mau meyakinkan kepada istrimu bahwa kamu seorang suami yang baik?" (Tertawa)."Kamu butuh berapa menit untuk membuat paragraph persuasi, Abdul? Lima belas menit?"

A : "Satu jam."

Pg : : "Tidak boleh satu jam. Itu terlalu lama."

A : "Em, susah ini."

\section{Translation:}

$\mathrm{Pg} \quad$ : "Maybe you want to convince your wife that you're a good husband?" (Laughs). "How many minutes you need to make paragraphs persuasion, Abdul? Fifteen minutes?"

A : "One hour."

Pg : : "Not to be one hour. It's too long."

A : :Em, it's difficult."

On speech acts is said illocution assertive. Speakers complained about the duties charged to him. It is seen in the speech, when Pg asked A about the time needed for the task and A as foreigners respond to such A question is not able to feel if he had to complete the task by the time offered by $\mathrm{Pg}$. Illocution assertive produce a report that is visible from A response stating that the task is too difficult if only provided time for fifteen minutes. So, this form of speech acts on this speech is complaining against the given task and time that are provided or offered by $\mathrm{Pg}$.

(2) $\mathrm{N}$ : "Nanti, nantibisabaca, ya?

Pg : : "Tidakbisabaca? Ya tulisan kamu harus bagus. Kalau tidak bagus tidak bisa dibaca".

J : : "Ibu jawabannya berbeda dengan maksud Num." (Tertawa)

Pg : "Laluapa?"

J : "Jadi, Numtanya, kalau presentasi boleh baca apa tidak, begitu."

\section{Translation:}

$\mathrm{N} \quad$ : "Later, later can read, huh?"

Pg : "Unable to read? Yes you should be writing good. If no good can't read."

J : : "Mom, your answer differs with the intention of Num." (Laughs)

Pg : "Then what?"

J : "So, the question is, if the Num presentation should read what is not, so."

On speech acts is said illocution assertive/representative. Speakers provide 
IJOLTL, Vol. 2, No. 3, September 2017

p ISSN: 2502 2326; e -ISSN: 2502 8278

Http://ijolt1.pusatbahasa.or.id; Email: ijolt1@gmail.com

Center of Language and Culture Studies, Surakarta, Indonesia

Budiasih, Tri Latifah; Andayani; Rohmadi, Muhammad. 2017. Illocution in Speech Acts

By Foreign Students in Indonesian as a Foreign Language Classes. IJOLTL (2017), 2(3): 213 226.

affirmation against the intent of the speech. $\mathrm{J}$ as speakers provide affirmation against the intent of the speech is about Pg Nm. in the speech, Nm asked Pg if at the moment of presentation is allowed read or not, but the response is different with the intention of $\mathrm{Pg}$ $\mathrm{Nm}$. J. who knows the meaning of speech $\mathrm{Nm}$ then explained and confirmed the intent of the speech is about $\mathrm{Nm}$ advance. So, this form of speech acts is said illocution assertive, where speakers ( $\mathrm{J})$ give you discernment towards partners (Pg) said about the intent of the speech earlier. Nm

(3) Pg : "Seperti kalimat, bagaimana kamu menulis. Bukan bagaimana kamu penulis.Ya? Disini ada kata pemanfaatan. Dari kata apa?"

Nm : "Manfaat."

J : :Tapi huruftibu itu seperti huruffkecil, tidak ada bedanya."

Nm : (Tersenyum). "Iya."

\section{Translation:}

Pg : "Such a sentence, how you write. Not how you author. Yes? Here there is the word utilization. From what word?"

$\mathrm{Nm}$ : "Benefits."

$\mathrm{J} \quad$ : "But your letter tlooks like a smallfis small, there is no difference."

Nm : (Smiles). "Yes."

On speech acts is said illocution assertive. $(\mathrm{J})$ speakers expressed opinions about the handwriting of the partners said $(\mathrm{Pg})$. When $\mathrm{Pg}$ wrote on the chalkboard and $\mathrm{J}$ give criticism about the letter $\mathrm{t}$ which are written with the same letter $\mathrm{f} \mathrm{Pg}$ and it is say yes by the $\mathrm{Nm}$. Words written is utilization, J noticed that the handwriting on the letter $\mathrm{t}$ and $\mathrm{Pg}$ $\mathrm{f}$ it makes no difference, so J gives an opinion on the writings of the Pg. So, this form of speech acts on this speech is giving opinions about what Pgdid, in this case the inscription Pg on the Board.

\subsubsection{Directive}

Illocution directive is a speech that aims to produce an effect to the partners said the form of action or have the intention to make the partners said doing something. Illocution directive found in Indonesian Language learning as follows.

(4) $\quad \operatorname{Pg} \quad$ : “Tidak bisa. Terlalu lama. Topik kita hari ini adalah persuasi. Persuasi itu meyakinkan agar seseorang percaya. Tapi kamu harus membuat dalam bahasa Indonesia. Berapa? Lima belas menit cukupya? Nedu, lima belas menit cukup?"

Nd : Tidak. Satu jam."

\section{Translation:}

Pg : "You can't. Too long. Our topic today is persuasion. Persuasion in order to convince someone to believe it. But you have to make in 
IJOLTL, Vol. 2, No. 3, September 2017

p ISSN: 2502 2326; e -ISSN: 2502 8278

Http://ijolt1.pusatbahasa.or.id; Email: ijolt1@gmail.com

Center of Language and Culture Studies, Surakarta, Indonesia

Budiasih, Tri Latifah; Andayani; Rohmadi, Muhammad. 2017. Illocution in Speech Acts

By Foreign Students in Indonesian as a Foreign Language Classes. IJOLTL (2017), 2(3): 213 226.

Indonesian. How much is it? Fifteen minutes is enough huh? Nedu, fifteen minutes enough?"

$\mathrm{Nd}$

: "No. One hour."

On speech acts is said illocution directive. Speakers are asked to give time for one hour to both partners in order to complete the task of the partners said. So, the form of acts of this nature in the speech is said to give effect on the partners said (Pg) in order to give more time to the speakers $(\mathrm{Nd})$. It looks at the partners said $(\mathrm{Pg})$ who asked the speakers $(\mathrm{Nd})$, to answer how much time it takes to complete the task. The speech is on $\mathrm{Pg}$ as a partner said offers to $\mathrm{Nd}$ who is foreigners about the time it takes to complete the task. Speakers to answer or respond to questions from the Pg form speech instructions or application so that the Pg gives time for one hour to $\mathrm{Nd}$ the task. So, the speech is intended to both partners $(\mathrm{Pg})$ do what is desired by the speakers $(\mathrm{Nd})$.

(5) Pg : "Ya, jadi ini tempat untuk mencari hotel online, ya. Situs jasa hotel, mencari hotel. Ok, sekali lagi." (Menayangkan iklan trivago).

B : "Susah!"

$\mathrm{Nm} \quad$ : "Terlalu cepat, sekali lagi!"

Pg : :Ya, Ok. Sekalilagi? Terlalu cepat? Sekali lagi ya?"

\section{Translation:}

Pg : "Yeah, so this is the place to find hotels online, yes. A website to looking for a hotel. OK, once again." (Serve ads trivago).

B : "It's hard!"

$\mathrm{Nm} \quad$ : "Too fast, once again!"

Pg : :Yes, Ok. Once again? Too fast? Once again, huh?"

On speech acts is said illocution directive. Speakers $(\mathrm{Nm})$ appealed to the partners said (Pg) to repeat the advertisement trivago because the ad $\mathrm{Nm}$ feel too fast so don't know what the content of those ads. So, this form of speech on speech acts is said to give influence to the partners said $(\mathrm{Pg})$ to do something like what is expected by the speakers $(\mathrm{Nm})$, in this rotating advertising trivago. It looks at the moment $\mathrm{Nm}$ responded by saying that the ads is too fast so he asked/begged partners said (Pg) to repeat the playback of those ads and approved by the partners said (Pg).

\subsubsection{Declarative (Declaratoins)}

Illocution declarative (declarations) is an included speech in the category follow highly specialized like said fire, giving the penalty, and appointed officers. It said acts intended to create things like status, circumstances and so forth from the speakers to the said partner (Yule, 1996:94). Illocution not found in declarative learning Indonesian Language. Illocution is very special, so it is not found in the form of declarative learning Indonesian Language on illocution. 
IJOLTL, Vol. 2, No. 3, September 2017

p ISSN: 2502 2326; e -ISSN: 2502 8278

Http://ijolt1.pusatbahasa.or.id; Email: ijolt1@gmail.com

Center of Language and Culture Studies, Surakarta, Indonesia

Budiasih, Tri Latifah; Andayani; Rohmadi, Muhammad. 2017. Illocution in Speech Acts

By Foreign Students in Indonesian as a Foreign Language Classes. IJOLTL (2017), 2(3): 213 226.

\subsubsection{Commissives}

Illocution commissives is a follow up said where the speakers attached to an action in the future. This includes follow up Commissives promising, offers, and swear (Rahardi, 2009:18) .IllocutionCommissives found in the Indonesian Language learning.

(6) Pg : "Termasuk kamu. Saya tahu kok." (Tertawa). "Num, ini sudah keempat kamu tadi bilang maju yang ketiga?"

$\mathrm{Nm} \quad$ : "Tapi aku mau yang terakhir." (Tertawa)

Pg : "Tadiketiga, terus keempat, sekarang terakhir?" (Tertawa).

\section{Translation:}

Pg : : "Including you. I know how." (Laughs). "Num, is already the fourth, you told me want to be the third?"

$\mathrm{Nm} \quad$ : "But I want to be the last." (laughs)

$\mathrm{Pg} \quad$ : "Last the third, the fourth, now thelast?" (Laughs).

On speech acts is said illocution commissive. Speakers promised partners said last time after presentation to his friends. So, this form of speech acts is promising something said. Speakers $(\mathrm{Nm})$ tied things with partners said $(\mathrm{Pg})$ to do something on the future. It is apparent from the speech that promised to get Nm turn presentation late, meaning that $\mathrm{Nm}$ had wished her to presentation after all her friend finished the presentation.

Pg : :Num, ibu pikir pas kamu masak itu kamu mau masakin buat ibu tetapi ternyata bukan."

$\mathrm{Nm} \quad$ : "Oh, bukan. Kalau ibu lain waktu."

\section{Translation:}

Pg : "Num, I thought you to cook for me but you didn't."

$\mathrm{Nm} \quad$ : "Oh, isn't it. Next time, mom."

On speech acts is said illocution commissives. Speakers (Nm) promising something to the partners said $(\mathrm{Pg})$, that is tied to something in the future. It looks at the moment the Pg gives a statement addressed to $\mathrm{Nm}$ about the cuisine. PG thought that $\mathrm{Nm}$ will provide certain dishes to $\mathrm{Pg}$. Speakers $(\mathrm{Nm})$ responded by promising that will fill out to Pg but at another time. In this case, promising something to the $\mathrm{Pg} \mathrm{Nm}$, artnya $\mathrm{Nm}$ is bound to do something in the future. So, this form of speech acts illocution commissives said is promising something in the future.

\subsubsection{Expressive}

Illocution expressive (expressives) is a follow up said that functions as a disclosure of psychological attitude of the speaker toward the State implied in the illocution. Illocution expressive found in learning Indonesian Language in 
IJOLTL, Vol. 2, No. 3, September 2017

p ISSN: 2502 2326; e-ISSN: 2502 8278

Http://ijolt1.pusatbahasa.or.id; Email: ijolt1@gmail.com

Center of Language and Culture Studies, Surakarta, Indonesia

Budiasih, Tri Latifah; Andayani; Rohmadi, Muhammad. 2017. Illocution in Speech Acts

By Foreign Students in Indonesian as a Foreign Language Classes. IJOLTL (2017), 2(3): 213 226.

Implementing Technical Unit Language of the SebelasMaret Universityas follows.

(8) J : "Ibu, hari ini saya membawa teman. Dia kuliah di Universitas Padjajaran. Maafkans aya terlalu sering membawa teman kekelas."

Pg : "Tidakapa-apa. Bawa saja temanmu biar bisa belajar bahasa Indonesia."

\section{Translation:}

A : "Mom, today I bring a friend. He studied at Padjajaran University. Forgive me to often bring friends into the classroom."

Pg : :It's okay. Just bring your friend to learn Indonesian."

On speech acts is said illocution expressives. Speaker apologized to both partners $(\mathrm{Pg})$ because the speakers brought his friend $\mathrm{u} \mathrm{n}$ to follow the teaching and learning activities in the classroom. So, the form of acts of this nature on the speech said the apology, speakers $(\mathrm{J})$ apologise to partners $(\mathrm{Pg})$ said, with the hope the partners said $(\mathrm{Pg})$ forgive and let him bring a friend $(\mathrm{J})$ speakers to follow the teaching and learning activities. So, the form of acts of this nature of said apology or expressive.

(9) M : "Mau makan. Kamu mau ikut?"

$\mathrm{Nm} \quad$ : "Tidak, terima kasih. Tadi sudah sarapan. Ini masih kenyang."

\section{Translation:}

M : "Want to eat. You want to come?"

Nm : "No, thank you. Earlier already had breakfast. It's still full."

On speech acts is said illocution expressives. Speakers $(\mathrm{Nm})$ thanked the partners said (M) because it's already offered to eat together. It looks at the moment of said partners $(\mathrm{M})$ asked the speakers $(\mathrm{Nm})$ are willing to eat together, and speakers $(\mathrm{Nm})$ responded with a polite. Speakers answering questions the form of expressive speech i.e. grateful because it already offers to eat together, but with the polite speech then the speakers explained that the last speakers (Nm) has breakfast and still full. So, this form of speech acts is saying thank you or expressives.

\subsection{Discussion}

Research on speech acts by Ariff and Mugableh (2014:248) emphasizes more on how speech acts occur by speakers of the form of speech in an agreement with different cultural backgrounds. The equation of the research with this research is equally research on speech acts. This research is more specific about the form of students illocution acts, whereas the research analyzes students' speech when making an agreement and body expression from men and women when making such an agreement. 
IJOLTL, Vol. 2, No. 3, September 2017

p ISSN: 2502 2326; e -ISSN: 2502 8278

Http://ijolt1.pusatbahasa.or.id; Email: ijolt1@gmail.com

Center of Language and Culture Studies, Surakarta, Indonesia

Budiasih, Tri Latifah; Andayani; Rohmadi, Muhammad. 2017. Illocution in Speech Acts By Foreign Students in Indonesian as a Foreign Language Classes. IJOLTL (2017), 2(3): 213 226.

Research on speech acts has been done by Suhirman (2016:19), in the journal IJOLTL with the title "Speech Acts in Psycholinguistics Classes Setting in Postgraduate Program". The study outlines what type of follow up said that occurred in class Psycholinguistics graduate program. Data on the take are sayings that resulted from an instructor/lecturer and students during the discussion in the classroom. Findings from research that is the use of three types of acts, namely locution, illocution and also perlocution. In contrast to these studies, this research focused on the acts of illocution, and only speech acts of the foreign students, instructors or teachers not being made of the data in the study.

Research conducted by Praditya, Putra, and the Artini (2014:1), describes the use of a speech acts film in the film said Habibi-Ainun. The findings in the study mentioned that the speech is made up of the direct speech, indirect speech, representatives, commissives, directives, and expressives. The equation with this research is located in research purposes i.e. describe acts of illocution. In addition, the study also not found illocution in the form of declaratives, it becomes the equation between such research with this research. However, in the study subjects were analyzed in the form of film Habibi-Ainun, while for the study was awarded feature resulting from foreign students in learning the Indonesian Language.

Research on the speech acts by Zayed (2014:1), discuss of a follow up on the use of the form of give a greeting, asking, give a thank, apologize, and give a praise. The point of this research out that in using the follow said during the ongoing learning, teachers use the speech is better at the moment gives, request, and saying a thank than using speech while apologize and member of praise. Unlike the speech is made by students, this research shows that students are better at using the follow said give greetings from on the type of speech acts. The difference with this research with the research is in the subject are examined, the research was more focused against acts of said illocution foreign students, while such research only describe about using the follow form give a greeting, asking, give a thank, apologize, and give a praise.

Umaroh and Kurniawati (2017:1), in his research, The Dominance of Illocution and PerlocutionIn The Transaction Of Buying And Selling, mentions that the use of illocution and perlocution in the transaction of buying and selling in the market the traditional Johar Semarang is more dominant. It is influenced by the background of research that generates a lot of speech is due to this heterogeneity. The research is similar to this research that is about illocution. However, the study also describes the use of perlocution speech, whereas in this study only focused on the illocution. This research is located in Johar Traditional Market, while the research is located in Language Technical Service Unit with the subject of research of foreign students

\section{CONCLUSION}

The act of speech illocution aims to state something in order to influence the said partner to do something according to what the speaker wants. The act of speaking of the illocution of foreign students found in Indonesian Language learning in Sebelas Maret University is in the form of acts of assertive/representative, directives, 
IJOLTL, Vol. 2, No. 3, September 2017

p ISSN: 2502 2326; e -ISSN: 2502 8278

Http://ijolt1.pusatbahasa.or.id; Email: ijolt1@gmail.com

Center of Language and Culture Studies, Surakarta, Indonesia

Budiasih, Tri Latifah; Andayani; Rohmadi, Muhammad. 2017. Illocution in Speech Acts

By Foreign Students in Indonesian as a Foreign Language Classes. IJOLTL (2017), 2(3): 213 226.

commissives, and expressives. In this study found three data of assertive, in the form of complaining, confirming something, and expressing opinions. Two directive illocution data are asking and pleading. Declarative illocution is not found in this study. Two expressive data in the form of apologizing and thanking. Thus, the act of speech of the illocution of foreign students is most often found in the act of assertive is complaining, affirmation, and opinion.

\section{REFERENCES}

Altikriti, Sahar Faroouq. 2011. Speech Act Analysis to Short Stories. The Journal of Language Teaching and Research ACADEMY PUBLISHER, 2 (6): 1374.

Anwar, Sanusi. 2014. Metodologi Penelitian Bisnis. Jakarta: Salemba Empat.

Ariff, Tun NurAfizah Zainal, dan Ibrahim Mugableh. 2013. Speech Act of Promising Among Jordanian. The International Journal of Humanities and Social Science, 3 (13): 248-266.

Austin, J.L. 1962. How to Do Things with Words. Cambridge: Harvard University Press.

Brown, H. D. 1994. Principles of Language Learning and Teaching. London: PrenticeHall, Inc.

Creswell, John W. 2003. Research Design: qualitative, quantitative, and method approached. California: Sage Publication, Inc.

Handayani, Tri Kartika, Sri Megawati, dan Lia Malia. 2016. Nilai-nilai Karakter dalam Tindak Tutur Illocution dalam Buku WIR BESUCHEN EINE MOSCHEE. The Litera Jurnal Penelitan Bahasa, Sastra, dan Pengajarannya, 15.(2): hlm. 306.

Ilyas, Sanaa, Qamar Khusni. 2012. Facebook Status Updates: A Speech Act Analysis. TheJournal Academic Research International, 3 (2): 501.

Isnawati, Fifin Dwi, Syamsul Anam, dan Sabta Diana. 2015. Speech Acts an Analysis of The Main Character in Shreek Movie Script. Jember: Publika Budaya.

Leech, Geoffrey. 2011. Prinsip-Prinsip Pragmatik (terjemahan M.D.D. Oka). Jakarta: U I Press.

Nadar, F. X. 2013. Pragmatik dan Penelitian Pragmatik. Yogyakarta: Grahallmu.

Rahardi, R. Kunjana. 2000. Imperatif Dalam Bahasa Indonesia. Yogyakarta: Duta Wacana University Press.

Searle, J. 1969. Speech Act An Essay in the Philosophy of Language. Cambridge: Cambridge University Press.

Sugiyono. 2015. Metode Penelitian Pendidikan (Pendekatan Kuantitatif, Kualitatif, dan $R \& D)$. Bandung: Penerbit Alfabeta.

Suhirman, Lalu. 2016. Speech Acts in Psycholinguistics Class Setting in Postgraduate Program. IJOLTL, 1(1):19-38.

Sulistyo, Edy Tri. 2013. Pragmatik: Suatu Kajian Awal. Surakarta: Sebelas Maret University Press.

H.B. Sutopo. 2002. Metodologi Penelitian Kualitatif. Surakarta: Sebelas Maret University Press. 
IJOLTL, Vol. 2, No. 3, September 2017

p ISSN: 2502 2326; e -ISSN: 2502 8278

Http://ijolt1.pusatbahasa.or.id; Email: ijolt1@gmail.com

Center of Language and Culture Studies, Surakarta, Indonesia

Budiasih, Tri Latifah; Andayani; Rohmadi, Muhammad. 2017. Illocution in Speech Acts

By Foreign Students in Indonesian as a Foreign Language Classes. IJOLTL (2017), 2(3): 213 226.

Umaroh, Liya, dan Neni Kurniawati. 2017. Dominasi Illocution dan Perlokusi dalam Transaksi Jual Beli. The Lensa: Kajian Kebahasaan, Kesusastraan, dan Budaya, 7 (1): 1-14.

Yule, George. 1996. Pragmatics. Oxford: Oxford University Press.

Wijana, I Dewa Putu. 1996. Dasar-dasar Pragmatik. Yogyakarta: PenerbitAndi.

Zayed, Niveen Mohammad. 2014. Jourdanian EFL Teachers and Students Practice of Speech Acts in the Classroom. The AUE: International Journal on Studies in English Language and Literature (IJSELL), 2: 1-10. 